Јован Б. Савин"

Универзитета у Београду

Филолошки факултет

Студент докторских студија https://doi.org/10.18485/analiff.2018.30.1.3 821.163.41.09-31 Црњански М. 821.111.09-31 Кларк А. Оригинални научни рад Примљен: 28.04.2018. Прихваћен: 21.08.2018.

\title{
КРУЖНО СХВАТАҢЕ ВРЕМЕНА У ДВА РЕПРЕЗЕНТАТИВНА ДЕЛА МИЛОША ЦРЊАНСКОГ И АРТУРА КЛАРКА
}

\begin{abstract}
У овом раду упоређују се романи Сеобе и 2001: Oguсеја у свемиру аутора Милоша Црњанског и Артура Кларка. Анализом структуре текстова обојице аутора примећена је сличност у погледу њиховог третирања времена као кружног понављања нових животних и еволутивних циклуса. Истраживање овог феномена у књижевности изискује интердисциплинарни приступ где се у обзир морају узети радови социолошких, историјских и антрополошких класика попут Шпенглера, Тојнбија и Кембела. Ова идеја је преко митолошких образаца одувек присутна у књижевности и стога је интересантна у погледу расветљавања, у основи сличних књижевних поступака код Црњанског и Кларка, чији јунаци следе готово идентичне матрице.
\end{abstract}

Кључне речи: Милош Црњански, Артур Кларк, циклизам у филозофији историје, мономит.

Дела Милоша Црњанског и Артура Кларка (Arthur C. Clarke) су на први поглед потпуно различита не само у погледу њихових садржаја који се баве различитим темама и мотивима, него и у погледу стила којим су написана као и временског контекста у којем су настала. То су два аутора који наизглед немају много тога заједничког. Први је уметнички сазревао у релативно малој култури у временима распада великих европских царстава на размеђи различитих цивилизација и њихових етноса. Други је типични представник англо-саксонске културе, а као аутор прославио се у жанру научне фантастике.

Филолошки Факултет, Студентски трг 3, 11000 Београд, Србија, yovansavin@, gmail.com 
Заједничко им је, међутим то што су обојица својим писањем далеко искорачили из културно-цивилизацијских образаца средина из којих су потекли. Тај искорак се код Црњанског види у његовој потреби да путује суштински схватајући људске односе и просторе на којима је боравио, непрестано се враћајући свом етносу, док је код Кларка то потреба да својим писањем човека смести у један знатно већу простор од онога који му припада на овој планети. Такве карактеристике, које се огледају пре свега у истанчаности њихових чула која су била способна да примете најситније детаље људске психе и историјских механизама, довеле су обојицу до великих остварења. Овде ћемо се бавити неким аспектима њихова два репрезентативна дела. То су Црњанскове Сеобе и Кларкова 2001: Oguсеја у свемиру (2001: A Space Odyssey). Поред бројних површинских разлика које се могу набројати у компарацији ова два романа, ипак се не можемо отети утиску да у дубљој структури они имају сличности јер се и Црњансков и Кларков јунак враћају трансформисани на исто место одакле су пре извесног времена кренули у своју авантуру. Неоспорна је чињеница да Вук Исакович и Дејвид Боуман описују иницијастички круг који је фаталан, јер коначно га затворивши, обојицу трансформише у нешто што они до тада нису били. У тексту који следи највише ће бити речи о симболичком кругу који не треба да буде схваћен дословно као геометријски облик, него пре свега треба имати на уму да су по свему судећи аутори о којима је реч, време, ту мистериозну просторно-временску димензију, схватали циклично.

У својој студији о обнови циклизма у филозофији историје која носи назив Скривени круі, Смилја Тартаља износи запажања међу којима је неоспорна чињеница да “се у разарање "пријатне идеје” прогреса на један посебан начин укључила и модерна теорија ярушиивено-истиоријских ичиклуса. Она је у себи сјединила стару идеју кружења, као основног тока свих друштава и цивилизација, и савремену научну апаратуру којом хоће да негира могућност напретка.” (Тарталја, 1976: 13). Посебну пажњу, између осталог, Тартаља поклања социолошко-историјским класицима попут Шпенглера и Тојнбија.

Рана античка космологија је у сталном кружењу видела поновљивост квалитета као законитост светских збивања, па се стога може закључити да су таква размишљања слична онима која данас 
КРУЖНО СХВАТАҢЕ ВРЕМЕНА У ДВА РЕПРЕЗЕНТАТИВНА ДЕЛА...

произилазе из закона о одржању материје. Други закон термодинамике каже да се ентропија затвореног система непрестано увећава. Овај феномен анализира се не само у модерној физици него и у многим сферама друштвеног живота, па и у књижевности. Идеју кружења друштвених уређења износи још Платон у осмој књизи Државе када један од учесника у дијалогу, Глаукон објашњава како се коначни облик владавине, демократија, захваљујући демагогији може распасти:

“А то распадање ће бити овако. Доба плодности и неплодности душе и тела постоји не само за биљке у земљи него и за жива створења на земљи. Ове мене настају када периодично обртање затвара круг у коме се свако биће креће, и то краткотрајну путању за сва бића која кратко живе и а дуготрајну путању за сва бића која живе дуго" (Држава: 545e).

Ову идеју критиковао је још највећи Платонов ученик, Аристотел, међутим његове замерке које су се односиле на механизме који обнављају круг нису оставиле виднијег трага утолико пре што је, како Тартаља каже: “Аристотел усвојио општехеленску космологију, задржавајући учење о “великој години” као времену у коме се све звезде враћају на своје место на небу, затворивши тако вечити круг збивања, и применио га на развој културе уопште.” (1976: 23). Из горе наведеног цитата из Платонове Државе најбоље се види да идеја поређења друштвених кретања са кретањима у природи, односно повезивање историјских циклуса са животним циклусима живих бића није новог датума. Отуда не чуди да Освалд Шпенглер већ у првом тому Пройаcйu Зaйaga износи тезу да су културе као организми прафеномен свеколике прошле и будуће историје. Он на једном месту каже “да свака култура пролази кроз животна доба појединог човека; свака има своје детињство, своје младалаштво, своју мужевност и своју старост", да би касније, негирајући дарвинизам то повезао са нејасном изјавом да "трајање једне генерације свеједно каквих бића јесте чињеница готово мистичког значаја". Шта год да је Шпенглер подразумевао под мистичним значајем, чињеница је да модерна медицинска наука, као ни физиологија још нису дале коначну реч о питањима која се тичу механизама старења организама. За ово истраживање, веома је важна Шпенглерова констатација да “свака култура, свако рано доба, успон и пропадање, сваки од њених унутарње нужних степена и периода, има одређено, увек исто, трајање, које се враћа увек снагом једног 
симбола". (Шпенглер, 1989: 163). Његов метод аналогије нас усмерава на учење једног ранијег истраживача и магистра биологије, Николаја Јаковлевича Данилевског који је своја биолошка знања покушао да употреби на културно историјска кретања. Цивилизације по Данилевском слично биљкама, почињу да умиру одмах након цветања. Овде необичну важност има природна смена годишњих доба која је, што ће касније бити анализирано код Црњанског, значајна за наставак разраде идеје о цикличном схватању времена. Смиља Тартаља је цитирајући фрагменте Данилевсковог дела, Русија и Евройа, приметила да "Данилевски утврђује да су разлози овог опадања исти као и код многих природних појава и процеса као што је време пролећа време кад је сунце највише на хоризонту а дан најдужи, док се резултати тог загревања сунчевог јављају тек у јулу и августу, као што јесен испуњава обећања пролећа, тако исто време опадања цивилизације почиње у доба кад она цвета и изгледа да је у зениту.” (1976: 61).

Да овде не би упали у замку погрешног схватања цикличних идеја историје, позваћемо се на рад Арнолда Тојнбија који је у својој обимној студији Исиираживање истиорије, између осталог изнео једну оригиналну идеју послуживши се том приликом метафором кочије чији точкови описују кругове а сама кола се ипак крећу линеарно напред. Овим Тојнби покушава да каже да описивање пуног круга точка историје није повратак на старо. Смиља Тартаља је покушавајући да критикује Тојнбијеву тезу да се људска историја понавља у генералним ритмовима универзума који за последицу ипак имају кретање унапред, расточила ту мисао изјавивши да точкови који би требали да представљају човечанство, “не додирују увек чврсто тле...” (1976: 133).

Видели смо дакле да су и Шпенглер и Тојнби под ударом критике још од самих зачетака својих промишљања. Поједине њихове идеје међутим преживљавају до данашњих дана из простог разлога што смо данас, читав век касније, сведоци поновног инересовања за цикличне историјско-социолошке идеје. Потребно је схватити да циклизам за који се залажу Шпенглер и посебно Тојнби није пуко понављање историје у дословним матрицама него је у питању рађање новог квалитета. Амерички антрополог Џозеф Кембел (Joseph Cambell) ce у својој студији о митовима Херој са хиљаgу лица (The Hero With a Thousand Faces) позива управо на Тојнбија када каже да се "расцеп у души као ни расцеп у друштвеном корпусу неће разрешити никаквим планом 
повратка у стара добра времена (архаизам) или програмима који гарантују некакву идеално замишљену будућност (футуризам), па чак ни најреалистичнијим, трезвеним напором да се поново повежу разједињени елементи. Само рођење може победити смрт - рођење, не поново старе ствари, већ нечега новог.” (Кембел, 2004: 29). Поменута Кембелова књига, у којој је разрађена теорија мономитиа, нас води до средишта ствари. Он идеју о кружном путовању јунака: ogвајање - инищијација - иоврайак види као нуклеус идеје мономийа која је у основи свих светских митова. Од памтивека до даншњих дана, херој се отискује од света свакодневице у подручје натприродних чуда: “Ту среће митске силе и извојује одлучујућу победу: херој се враћа из те тајанствене авантуре с моћи да подари нешто добро својим саплеменицима." (Кембел, 2004: 39).

Поменуту схему можемо да уочимо и недвосмислено пратимо и у настаријем књижевном делу човечанства, Eйy о Гилїамешу. Ово је сумерско - акадска прича о полубожанству, владару и јунаку који у потрази за вечним животом чини бројна херојска дела, међутим ипак доживљава неуспех и коначно се враћа у свој родни град Урук где га “смрт уграби у сјајној дворани његове палате".

У Сеобама Милоша Црњанског већ у првом поглављу које носи назив Бескрајни, йлави круї. У юему, звезgа, јасно је да се главни јунак Вук Исакович спрема да са својим војницима крене на свој пут иницијације. Пролеће је 1744 године. Период рата за аустријско наслеђе (1740 - 1748). Српски живаљ који је пре нешто мало више од пола века раније дошао на просторе јужне Угарске настањен је у пограничним областима негостољубивих мочвара равнице и по потреби се ангажује у ратовима Хабзбуршке монархије и њених противника у разним деловима Европе. И док размишљајући о пролећу Томас Стернс Елиот (Thomas Stearns Eliot) у Пустиој земљи (The Waste Land) а у преводу Ивана В. Лалића каже да је “април најсвирепији месец, што гаји јоргован из мртвог тла, меша успомену и жудњу и подстиче тромо корење пролећном кишом", код Црњанског “магловити врбаци испаравају, облаци се ковитлају наниже, река је мутна и непроходна а земља је тамна, невидљива и кишовита". Сахрана мртваца и полазак у рат са пролећем које би требало да буја од живота представљају код обојице један поглед, помало искоса на живот и смрт. Драшко Ређеп у уводној 
речи своје антологије о Црњанском примећује да се “сва годишња доба, изненадна једнако као и очекивана, јављају у његовој раскошној литератури као специфичан, неумитан метроном свакојаких судбина, стања и расположења.” (Ређеп, 1993: 5). Ређеп говори о стањима. То је битно поново приметити јер је још Милан Богдановић у свом приказу Сеоба који се појавио 1929. године у Срйском књижевном іласнику приметио да “овај роман не развија збивања, већ даје једно стање”. Богдановић описује лирску атмосферу романа у виду непрекидног кретања и на једном месту у тексту Исаковича представља као инкарнацију психологије бунила где је, у атмосфери сна и магле, он “живи фантом, једна моћна сенка свог народа и лирска синтеза свег његовог психолошког хаоса”. (Богдановић, 1929: 57). Овде треба приметити, уколико смо добро схватили Богдановића, да се оставља простор за још један круг кроз чије етапе иницијације пролази цео српски народ. “Сеобе” као појам се дакле схватају не само као Исаковичев утопијски сан о бескрајним руским пространствима, него као излазак и пресељења појединих делова српског народа. Тај круг се, барем у случају сентандрејских Срба коначно затвара оййачијама, масовним повратком читавих породица у отаџбину у периоду између два светска рата и након Другог светског рата. Тим историјским чином почеле су да се испуњавају пророчке речи Јакова Игњатовића за кога је и са̂м Црњански у својим есејима рекао да "није умео да буде нежан, али очај његов и простаклук, који се тако мало свидео академцима, нежнија је нежност од свих нежности”. (Црњански, 1991: 94). И заиста, имали ишта нежније и потресније од Игњатовићевих речи из његових бележака о Сентандреји где каже: “И кад у Сентандреји једном нестане Срба, а једаред ће их нестати, онда ће им обронак дивних планина бити гроб, покров мирисаво зеленило, звук звона њихових храмова пропратиће их у вечност, а храмови остаће као споменици њиховог духа и живота”. (Игњатовић, 1951: 296).

Главни јунак Сеоба пред Стразбуром размишља о догађајима из прошлости свог живота, сећа се младости и оца који му је “пунио главу о повратку у попаљену и поклану, опустелу Сербиу”. Недостају му деца и жена а у памети му остадоше "само оне сјајне, чисте звезде, и сребрне шумске путање над којима се спушта априлска магла, којима је пројахао у прве дане свога брака са женом, живећи у оној једноликој досади мале славонске посаде, ловећи лисице, а у будућности, 
само та безгранична, завејана Русија, куда мишљаше да се одсели, да би једном лакше живео и да би се већ једном одморио и смирио". (Црњански, 2008: 155). Схвата да му је живот прошао и да га поправити не може. И тада се њему, у једном специфичном тренутку који представља кулминацију његовог сазнања да се ствари неће и не могу поправити, учини његов пук дражим од свега на свету, а онима што остадоше дома, пожеле да им коначно сване. Овде се ради о моменту осећаја љубави према својим најближима али и према целом народу. Сличан алтруистички чин можемо да нађемо и код већ поменутог Гилгамеша који травку бесмртности, тај чаробни цвет мора који је изронио жели да подели са својим народом. Међутим, Гилгамешу змија краде травку што га нагони на горке сузе, коначни пораз и повратак у Урук где умире. Чини се да је преломни тренутак код Исаковича моменат пред Стразбуром кад он “зажуде за нечим надземаљским не само за себе, већ и за своје”. Полако тонувши у сан он осети “да је преварен, понижен, а да беше рођен за нешто чисто, светло, ванредно и непролазно". (Црњански, 2008: 158).

Повратак је за Исаковича болно искуство, јер након разочарења и губљења наде да ће онима што остадоше дома икада сванути, сазнаје и болну вест да му је жена Дафина преминула. Љубавни троугао између њега, брата му Аранђела и супруге “госпоже Дафине” је паралелна прича која се може издвојити из главног тока романа. Њих троје су личности чије се постојање може представити једним троуглом чија се темена окрећу у раније описаном кругу. После растанка на самом почетку књиге ово троје људи се више не састају до краја. Аранђел не долази под Петроварадин да сачека свога брата него се сели у Будим, а Дафинин гроб Вук ће посетити тек сутрадан по повратку. Затворивши свој круг у Сеобама Црњански нам понавља реченице са самог почетка књиге које нам дословце указују на природни циклус понављања ствари:

“Све је било као и при његовом поласку. Магловити врбаци испараваху се, облаци се спуштаху све наниже. Земља је била само тамна влага, невидљива и кишовита." (2008: 240).

Нови круг отпочиње Вуковим плановима и размишљањем о обавезама које га чекају у данима који следе где “треба ићи патријар- 
ху, дознати новости, спремати се за Беч, спасавати војнике од нове сеобе и одузимања оружја, мислити на децу, ићи брату у Будим, ђенералу у Темишвар, куповати коње, кола, подићи ковачницу у селу, преместити капетана Антоновича, писати исцрпан извештај о повратку Славонско - подунавског полка, а нарочито, нарочито спремати план, извидети могућност одласка у Русију, куда се још увек надао да ће отићи" (2008: 241). Што се другог круга тиче, оног круга што га народ својим сеобама описује, његов нови циклус можда отпочиње, можда jе већ отпочео и завршио се, а можда ће се то тек догодити у будућности коју Црњански у умерено оптимистичком тону види у завршним речима Сеоба:

“Зрно, што је у његовој старости сачувало у себи моћ да проклија и наднесе нова бића над времена и небеса, која ће се огледати у водама што се сливају и састају, ту, испод Турске и Немачке, огледати и надносити као мостови." (2008: 242).

Артур Кларк у роману - 2001: Oguсеја у свемиру, слично Црњанском уводи два круга, или циклуса иницијације по којима ће да крену човечанство у целини и појединачни јунаци оличени у ликовима човеколиког мајмуна Гледа-Месеца (Moon-Watcher), др Хејвуда Флојда, научника задуженог за тајну мисију усмерену ка планети Сатурн и

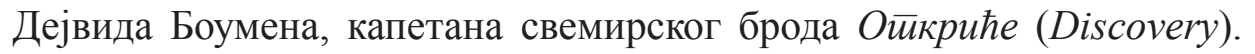
Последњу тројицу можемо да посматрамо као једног јунака, као еволутивни напредак човека од примитивног бића, преко разумног човека који је овладао многим технологијама и осваја свемир напустивши своју матичну планету и коначно као људско биће које физички одлази даље од свих припадника своје врсте на трансцедентални пут ка једном новом облику постојања.

Сиже Кларковог романа лакше је пратити уз помоћ слика које су нам остале дубоко урезане у свест захваљујући ремек делу филмске индустрије, филму којег је режисер Стенли Кјубрик (Stanley Kubrick) снимио 1968. године по Кларковом сценарију писаним паралелно са романом. У питању је идеја о веома напредној цивилизацији која је у освит човечанства на нашој планети оставила артефакт у облику паралелопипеда (у коментарима дела назван монолийом) који је, испоставиће се, својеврсна машина за учење јер у његовом прису- 
КРУЖНО СХВАТАњЕ ВРЕМЕНА У ДВА РЕПРЕЗЕНТАТИВНА ДЕЛА...

ству наши преци, који су на ивици изумирања почињу да користе свој ум. Моменат када они схватају да кости угинулих животиња могу да послуже као оружје у филму је представљен легендарном секвенцом када Гледа-Месец животињском бутном кости ломи костуре животиња, обрачунава се са ривалским племеном своје врсте око превласти над једним извором воде где убија припадника своје врсте и коначно баца исту кост чији лет представља људску еволуцију дугу три милиона година јер се кост на крају кадра претвара у свемирски брод у Земљиној орбити. У роману је моменат пробуђене људске свести, након што су Гледа-Месец и његови саплеменици савладали леопарда који их је извесно време терорисао, дочаран ништа мање ефектним пасусом:

“Неколико секунди Гледа-Месец је стајао несигурно над својом новом жртвом, покушавајући да појми необичну и чудесну чињеницу: мртав леопард и даље је био кадар да убија. Сада је био господар света, али није сасвим знао шта му је чинити. Но, нешто ће већ смислити.” (Кларк, 1983: 26).

У двадесет првом веку на Месецу бива пронађен идентични монолит који је, како сва истраживања показују, намерно закопан. То је уједно, како Кларк у роману каже, и највеће откриће у историји науке jep је у питању непосредни доказ постојања ванземаљске инелигенције. Док се др Флојд спуштао у удубљење да би из непосредне близине осмотрио мистериозни ванземаљски артефакт, испуњен осећањем страхопоштовања и беспомоћности, наратор нам указује да је овде, код самог портала Земље, човек стајао лицем у лице са једном тајном која можда никада неће бити одгонетнута. "Пре три милиона година нешто је минуло овуда, оставило за собом овај недокучен и можда недокучив симбол властите сврхе, а затим се вратило ка планетама или ка звездама". (1983: 66). Након што га је први пут након толико дугог периода обасјало лунарно сунце, монолит шаље кратак сигнал у правцу Сатурна. Ускоро бива организонвана мисија која новог јунака Дејвида Боумена води ка Сатурну где се сусреће са монолитом много већих размера који представља “капију звезда” кроз коју он пролази доживљавајући иницијацију и коначну трансформацију у “дете звезда”. Новица Петровић у својој студији Човек и космос у gелу Аримура Кларка и Сйанислава Лема каже да “апотеоза људске јединке по имену Дејвид Боуман, којом је имплицитно наговештена потенцијална апотеоза читаве људске расе, 
засигурно представља највишу тачку Кларковог антрополошког оптимизма, како у идејном тако и у уметничком смислу”. (Петровић: 2011, 132). Ентитет који је некада био припадник људске врсте, Дејвид Боумен, сада назван “Дете звезда”, на крају романа, вративши се до Земље затвара одисејевски круг нараторовим речима: “Јер иако је сада било господар света, није сасвим знало шта му надаље ваља чинити. Но нешто ће већ смислити.” (Кларк: 1983, 184).

Кларк је попут Црњанског посегао за истим књижевним поступком понављања истоветних реченица са почетка своје књиге. То међутим не значи да се све истоветно понавља, него у истим матрицама добија један нов квалитет и осећајност. Јер као што Вук Исакович затиче пејзаже "Нове Сербие” потпуно исте у Црњансковим описима, али већ сутра планира нове акције, тако ни за “Дете звезда" које се враћа истоветној Земљи не знамо колико је спремно да изведе људску врсту из сенке космичке усамљености.

\section{Литература}

Анйолойија Црњански. (1993). Избор, предговор и напомене Драшко Ређеп. Нови Сад: Прометеј.

Eū o Гилїамещу. (2009). С немачког превео Станислав Препрек. Београд: Завод за уџбенике.

Игњатовић, J. (1951). Ogабрана gела. Нови Сад: Матица српска.

Кембел, Џ. (2004). Херој са хиљаяу лица. Нови Сад: Стилос.

Кларк, А. (1983). 2001: Oguсеја у свемиру. Превели Зоран Живковић и Жика Богдановић. Београд: Народна књига.

Платон. (2002). Држава. Превели Албин Вихлар и Бранко Павловић. Београд: БИГЗ.

Петровић, Н. (2011). Човек и космос у gелу Арйура Кларка и Сйанислава Лема. Београд: Конрас.

Тартаља, С. (1976). Скривени круї. Београд: Председништво Конференције ССОЈ. Тојнби, А. (1970). Истираживање исйорије. Превео Миодраг Лукић. Београд: Просвета.

Црњански, М. (1991). Есеји. Нови Сад: Књижевна заједница Новог Сада.

Црњански, М. (2008). Сеобе. Приредио Мило Ломпар. Београд: Штампар Макарије: Октоих.

Шпенглер, О. (1989). Пройасӣ Зайаga. Превео Владимир Вујић. Београд: Књижевне новине. 
КРУЖНО СХВАТАҢЕ ВРЕМЕНА У ДВА РЕПРЕЗЕНТАТИВНА ДЕЛА...

Jovan Savin

\section{Summary \\ THE CYCLICAL UNDERSTANDING OF TIME \\ IN TWO REPRESENTATIVE WORKS OF MILOŠ CRNJANSKI AND ARTHUR C. CLARKE}

This paper deals with the comparison of the two representative novels of M. Crnjanski and A.C. Clarke: Migrations and 2001: A Space Odyssey. The structural analyses of both texts showed similarities in respect of the treatment of time which both authors represented by the repetition of new life and evolutionary cycles. Investigation of this phenomenon requires an interdisciplinary approach to the subject matter which includes the implementation of the classics by Oswald Spengler, Arnold Toynbee and Joseph Campbell. This mythological idea is incorporated in the literature since ancient times and it is the part of Crnjanski and Clarke's literary procedures whose literary characters follow the similar patterns.

Key words: Miloš Crnjanski, Arthur C. Clarke, cycles in the philosophy of history, monomyth. 